\title{
Trzy razy o wymyślaniu sobie życia
}

Images

vol. X/no. 19

Poznań 2012

ISSN 1731-450X

Zadanie wygląda na dość proste. Należy znaleźć ciekawego bohatera i przedstawić jego historię. Wydaje się, że każdy z mijanych codziennie na ulicy ludzi mógłby powiedzieć dużo o sobie, każdy z nas przeżywa przecież chwile smutku, niepokoju i radości. Nowy dzień przynosi wiele niespodzianek, a i echa przeszłości wyraźnie wpływają na tu i teraz. Znalezienie więc postaci, której działanie i przeżycia są interesujące, nie powinno być rzeczą trudną. Należy też zadać pytanie: Komu chcemy opowiedzieć ową historię? Wszakże to, czy coś jest ciekawe, niewątpliwie zależy także od odbiorcy. Przed takimi dylematami stają studenci szkół filmowych, także tej z Łodzi, kiedy ich zadaniem jest realizacja etiudy filmowej. $\mathrm{W}$ tej krótkiej formie muszą opowiedzieć historię, którą sami uważają za interesującą i która ma potencjał, aby zainteresować innych.

Pierwszy warunek w filmach, o których będzie mowa, został spełniony. Wszystkie mają świetnie wyeksponowanego, ciekawego bohatera, który skupia całą uwagę widza na sobie i na działaniach, które w życiu podejmuje lub których w życiu unika. Michał z filmu Sinner (reż. Kalina Alabrudzińska), prawniczka z Królowej Śniegu (reż. Klara Kochańska) oraz Robert z Zaśpiewaj mi do snu (reż. Magnus Arnesen) żyją, wydawałoby się, podobnie jak my. Ich egzystencja nie ma szczególnych rysów. Dla twórców tych filmów zauważalne i ciekawe stają się rzeczy małe. To one czynią z bohaterów ich etiud postaci szczególne. Alabrudzińska i Kochańska korzystają z konwencji etiudy dokumentalnej, Arnesen wspiera się pierwowzorem literackim, adaptuje opowiadanie Frode Gryttena.

Sinner to film o Michale, który prowadzi kursy uwodzenia kobiet (projekt „Realna metoda skutecznego podrywu”). Tytułowy grzesznik uczy nas (tzn. nas samców) i uczestników tych kursów, jak stać się lepszą wersją mężczyzny. Obserwujemy zarówno zajęcia praktyczne, jak i teoretyczne. Jednakże zderzenie edukacyjnych rewelacji Michała z rzeczywistością okazuje się dość bolesne. Jego uczniom przekucie w czyn zaleceń mistrza podrywu nie przychodzi łatwo, a nawet jemu samemu trudno namówić kobietę na spotkanie (nawet nie „umówić się"), co obserwujemy w finale filmu. Stworzona przez niego koncepcja zawodzi u podstaw. Nie wychodzą mu nawet rozmowy przez telefon, nie mówiąc już o spotkaniach w tzw. realu.

Obserwujemy zaledwie jedną scenę, w której Michał znajduje się w towarzystwie kobiety. To sesja zdjęciowa, podczas której dziewczyna ma grać niedostępną. Taka sytuacja wyraźnie chłopakowi nie odpowiada. Nie potrafi się w niej odnaleźć i - jak to się już wcześniej 
zdarzało - pozostaje zajęty tylko własną osobą. Jest w filmie jeszcze inna ważna scena, która zdaje się odnosić wprost do takiego obrotu rzeczy. Oto Michał rozmawia przez komunikator internetowy z matką. Kobieta utwierdza go w przekonaniu o jego ponadprzeciętnej urodzie i wróży mu karierę aktorską w Hollywood.

Rzeczywistość jest jednak bardziej brutalna, o czym świadczą castingi, na których Michał nie potrafi sprostać postawionemu mu zadaniu. Znawca kobiet w teorii - praktykiem okazuje się kiepskim. Bliskość dwojga ludzi okazuje się nie być chwytem marketingowym, o czym próbuje on nas przekonać. Co ciekawe, również Kalina Alabrudzińska w swoim filmie odnosi się do tej kwestii, obnażając wyrachowanie trenerów i sztuczność tego rodzaju projektów.

Takich problemów zdaje się nie mieć bohaterka filmu Klary Kochańskiej Królowa Śniegu. W pierwszych ujęciach filmu widzimy uśmiechniętą kobietę, która $\mathrm{z}$ okien samochodu obserwuje paryską wieżę Eiffla. Za kamerą (ujęcia á la home video) znajduje się mężczyzna, z którym dziewczyna ma świetny kontakt. Potem mężczyzna już się nie pojawia. W filmie za to obserwujemy zajęcia, które skrzętnie i regularnie wypełniają życie kobiety. Mieszkanie jak z katalogu, praca w kancelarii prawniczej, ustabilizowany dzień, w którym zawsze pojawiają się te same czynności, wykonywane z ogromną starannością. Seria ćwiczeń, pielęgnacja ciała, śniadanie, basen i kurs tanga, który jest praktycznie jedyną okazją zaznania bliskości z drugim człowiekiem. Wszystko to dzieje się w sterylnych, śnieżnobiałych wnętrzach, co powoduje, że kobieta postrzegana być musi jako pogrążona w samotności, a jej życie jako naznaczone potrzebą spełnienia i odnalezienia siebie w świecie. Na pierwszy rzut oka kobieta ma wszystko. Bo jest też jakaś rodzina, z którą, podobnie jak Michał z Sinnera, kobieta rozmawia za pośrednictwem internetu.

Film Kochańskiej opowiada o zjawisku żywo dyskutowanym, aktualnym. Single zostali już rozpracowani w opracowaniach naukowych, dla nich tworzy się specjalne strony internetowe, oferty sklepów, biur turystycznych, klubów czy restauracji. Osoby te stają się celem marketingowców i reklamowych strategów. My przyglądamy się singielce, która zapewne $\mathrm{z}$ tych, kierowanych specjalnie do niej, ofert korzysta. To wszystko jednak nie przynosi naszej bohaterce ani szczęścia, ani spełnienia. Poza kursem tanga nic w jej życiu nie iskrzy.

Reżyserka filmu świetnie ukazuję tę jedyną iskierkę, głównie poprzez kolorystykę i dynamikę ujęć z Milongi. Czerwony kolor, symbol miłości, a także bliskie ujęcia ukazujące namiętność argentyńskiego tańca wzbudzają nadzieję na możliwość zmiany losu prawniczki. Jednak po chwili nadzieja ta zostaje zgaszona. Wracamy do naturalnych barw, kroki uczestników kursu stają się powolne, pozbawione emocji i napięcia. Wszyscy wokół siebie tylko krążą, nie pozostawiając sobie szans na prawdziwą miłość. Film Królowa Śniegu mógłby stać się więc manifestem przeciwników singielskiego stylu życia. Życia 
ustabilizowanego, uregulowanego jak w najlepiej skomponowanym kalendarzu, ale przede wszystkim nieszczęśliwego i samotnego.

Do sytuacji damsko-męskich wracamy przy okazji filmu Magnusa Arnesena Zaśpiewaj mi do snu. 45-letni Robert wiedzie swoje ustabilizowane życie u boku umierającej na raka matki. Jest cichym buntownikiem, pokątnie zrywa kwiaty z przydomowych ogródków, porzuca swoją pracę, bo szef wymaga od niego noszenia nielubianego przez niego uniformu. Ma być takim samym pocztowcem jak jego koledzy i koleżanki z pracy. Robert woli jednak do pracy zakładać dżinsy, bluzę z kapturem i koszulkę z nazwą swojej ulubionej kapeli The Smiths. Mimo buntowniczego charakteru jest przygaszony. Jego twarz nie wyraża praktycznie żadnych emocji, nawet wtedy, gdy przyjeżdża do domu i przygląda się agonii swojej matki. Matka, świadoma tego, że za chwilę odejdzie na zawsze, martwi się o przyszłość Roberta, nie chce, żeby został sam. Ten więc wymyśla „piosenkę”, którą zaśpiewa jej do ostatniego snu. Piosenka jest równocześnie bajką, która ma ukoić nie tylko niepokój matki, ale także Roberta.

Wyrusza na poszukiwanie „swojej” dziewczyny lub kogoś, kto będzie ją udawał. Dopiero podczas powrotu do domu, kiedy jest już zrezygnowany, w ostatniej chwili odnajduje idealną kandydatkę, która zgadza się odegrać najważniejszą rolę w tej bajce. Matka z łatwością odkrywa intrygę uknutą przez Roberta i Ingrid-Marit. Mimo to umiera spokojnie, ponieważ wie, że Robert po jej śmierci poradzi sobie i w swoim spokojnym, wyciszonym życiu odnajdzie szczęście. W finale filmu obserwujemy Roberta wychodzącego na przystań, czekającego na statek, na którym przybędzie Ingrid-Marit. Przybycie tego statku być może zmieni jego życie. I choć wcześniej wydawało się, że miłość nie jest mu potrzebna do szczęścia, teraz wiemy, że w ustabilizowanym życiu Roberta jest sporo miejsca, które wypełnić może kobieta.

Spokojny, kameralny film Arnesena pokazuje, jak silna i ważna jest bliskość drugiego człowieka. Bliskość, która każe wypełnić każdą prośbę, nawet taką, która stoi w sprzeczności z naszą naturą. Robert spełnia dla matki jej ostatnie życzenie, ale spełnia też swoje marzenia, poznaje kobietę, która może stanie mu się równie bliska jak zmarła matka. W lirycznym sztafażu, w otoczeniu norweskich fiordów oglądamy historię człowieka, którego życie odmieniła nadzieja. Nadzieja, która wyrosła $z$ jego wielkiej tragedii.

Pięknie skomponowane kadry, w których otrzymujemy tę opowieść, tworzą niepowtarzalną atmosferę filmu. Magnus Arnesen ukazuje świat swoich rodaków, świat pełen spokoju, nadziei, ale też życiowych dramatów. Otwarte zakończenie etiudy wzbudza u widza poczucie prawie że idylliczności tego świata, w którym kolor kwiatów, rytm życia przyrody jest krajobrazem dla życia spełnionego, otwartego na to, co nowe.

Te trzy filmy zrealizowane przez studentów łódzkiej filmówki łączy pragnienie opowiedzenia o współczesności. Jej wielobarwność 
objawia się w tematyce podjętej przez twórców. Główną cechą naszych czasów wydaje się być - według Alabrudzińskiej, Kochańskiej i Arnesena - samotność. Każdy z twórców pokazuje widzom inną receptę na jej przezwyciężenie. Możemy zapisać się na kurs podrywu i stać się bezczelnym i cynicznym macho, możemy też nic z tym nie robić, zamknąć się w świetnie wyposażonym mieszkaniu i zrytualizować swoje życie do najdrobniejszych, powtarzalnych czynności. Możemy też dostać od losu mały sygnał, który wywoła w nas impuls do walki o swoje szczęście.

Współczesność pozostaje w diagnozach tych twórców wielobarwna i otwarta. To, co w tych filmach jest najważniejsze, to brak jakiejkolwiek dydaktyki. Choć Michał z Sinnera nie wzbudza mojej sympatii, a życie prawniczki z Królowej Śniegu nie wydaje mi się w najmniejszym stopniu ciekawe, to z ogromnym zainteresowaniem przyglądałem się ich walce o to, co dla nich ważne. Studenci filmówki z pełnym zaangażowaniem pokazują różne możliwości wyboru własnej drogi życiowej. I to właśnie jest najbardziej interesującym „materiałem na film” dla Alabrudzińskiej, Kochańskiej i Arnesena - otwartość świata i możliwość kształtowania własnego życia w poszukiwaniu szczęścia. 